\title{
Towards a new process-centric approach of social mediation management in Morocco
}

\author{
Yousaf Khiat $^{1}$, Hassan Nachifa ${ }^{2}$ and Mohammed Ftouhi ${ }^{3}$ \\ 1 Faculty of the Science of Education, University Mohammed V \\ Rabat, Morocco \\ 2 National Institute of Statistics and Applied Economics, University Mohammed V \\ Rabat, Morocco \\ ${ }^{3}$ Faculty of the Science of Education, University Mohammed V \\ Rabat, Morocco
}

\begin{abstract}
In our field study of social mediation in the context of fighting against Slums in Morocco, we found that the causes of these operations failures are mainly due to the absence of a framework that describes the different processes to implement in order to ensure a better governance of this kind of project which has economic, social and cultural impacts.

Our contribution is to put in place a new process-centric approach to provide social mediators with a framework to formalize and structure the practices of the mediation business.

The proposed framework is composed mainly of the following elements:

- General mapping of macro processes,

- Processes sheets (Processes details)

- The distribution of processes over the different project phases.
\end{abstract}

Keywords: Process Management, Framework, E-Government, Social Mediation, Project Management.

\section{Introduction}

Social mediation in Morocco is a discipline of territorial governance representing a major importance regarding its socioeconomic impacts on citizens in particular and also on the general economic situation of the country [6][7][8].

In this paper, we propose a process-centric approach for structuring social mediation activity in Morocco, based on numerous findings on this field.

The proposed framework is composed mainly of the following elements:

- General mapping of macro processes,

- Processes sheets (Processes details)

- The distribution of processes over the different project phases.

\section{Process-centric approach of social mediation management in Morocco}

Process control involves monitoring the performance of the process through well-chosen indicators to assess potential and opportunities for improvement. In projects involving the social mediation of slum resorption, the aim is to capitalize on the current system to lead and drive social mediation through processes.

Regarding [1], a process is "a sequence of events that uses inputs to produce outputs .... From a business perspective, a process is a coordinated and standardized flow of activities performed by people or machines, which can traverse functional and departmental boundaries to achieve a business objective that creates value for internal and external customers".

Moreover, the process approach is a method of analysis and modeling. It consists in describing in a methodical way the organization and the activities in order to act on it.

The first step is to identify the sequence of activities (called process) that must be carried out to transform a demand into a product or service that satisfies this demand. Then, the organization and the necessary means are determined, process by process.

The process approach is put at the forefront as a tool for improvement and management.

In this context, the ISO 9001 standard gives improvements to recommendations that should enable an organization to 
improve the quality of its products / services and to satisfy its customers through:

- Identification of key processes,

- Determination of sequences and interactions between processes,

- Determination of the necessary criteria and methods for processes improvement,

- Provision of the necessary resources (resources and information) for the execution and monitoring of these processes,

- Planning for continuous improvement to ensure process quality

- Process mapping which is a graphical representation of processes and their interaction.

Indeed, the key processes of social mediation are at the level of three phases: project start-up, implementation, evaluation and closure.

The initiating process is usually started by the political authorities and the project owner as part of a social policy.

It is followed by the execution process which represents the realization of what was planned in confrontation with reality. The declination of this process takes place at regional and local level. It is coordinated in practice by the local board. At the end, it is closed by the evaluation and closure phase.

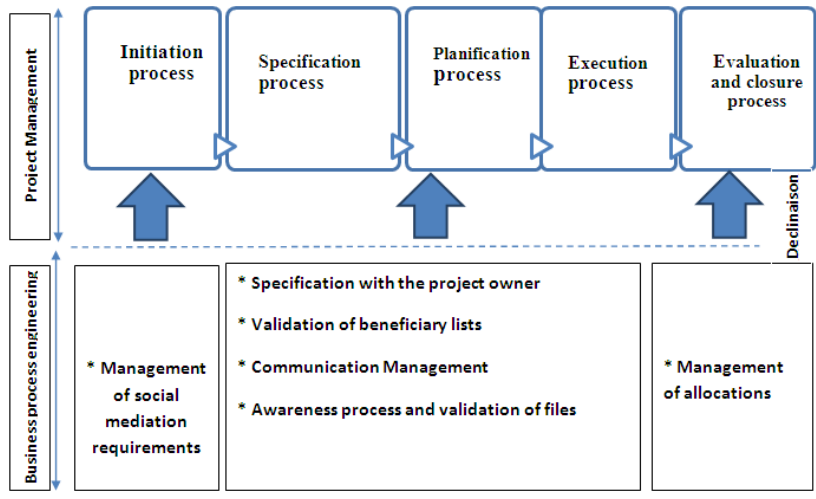

Fig. 1 Monitoring of the social mediation project

Social Mediation: General macro process mapping

Starting from these large processes families, as shown in Figure (Fig. 1), we can propose a general mapping from design, which means inputs, to final realization through outputs.

H. Branderburg and J,P. Wojtyna define, in their book [2], the processes mapping "as a graphic way of restoring the identification of processes and their interaction"
The start of the project emanates from a governmental will, which is operationalized by a policy translated by a budgetary financing and declined towards the different bodies operating in space and territory.

The first step is to set up the project milestones by:

1. Requirements management (initiating the project) by starting and validating three main processes (elaboration of specifications, call for proposal, contract ...). The objective is to focuses on understanding stockholder's needs, which should be detailed and elicited enough to be used in the implementation and monitoring of project activities[5]

2. Implementation and execution: it is composed of the following processes: (specification and planning with the project owner, validation of beneficiary lists, management of communication, reception and awareness raising, validation of files)

3. Evaluation and closure: it is carried out by the transfer of the beneficiaries and the demolition of the barracks

Thus, we can summarize the major processes and derived processes as illustrated in the following diagram (Fig 2).

\section{Roles and responsibilities:}

The distribution of roles and responsibilities in the social mediation project can be done according to the RACI matrix. This avoids duplicating roles, wasting time and clearly definition of each responsibility at different levels.

RACI is an acronym derived from the four key responsibilities most typically used: Responsible, Accountable, Consulted, and Informed [3]:

- R: Responsible (Those who do the work to achieve the task.)

- A: Accountable (The one ultimately answerable for the correct and thorough completion of the deliverable or task[4])

- C: Consulted (Those whose opinions are sought [4])

- I: Informed (Those who are kept up-to-date on progress, often only on completion of the task or deliverable[4])

This tool allows you to quickly visualize who does what as shown at (Table 1):

- The operational members of the project and their respective tasks

- The unique responsible of the task

- The actors who can be solicited as advisers

- People who must be informed of the task 

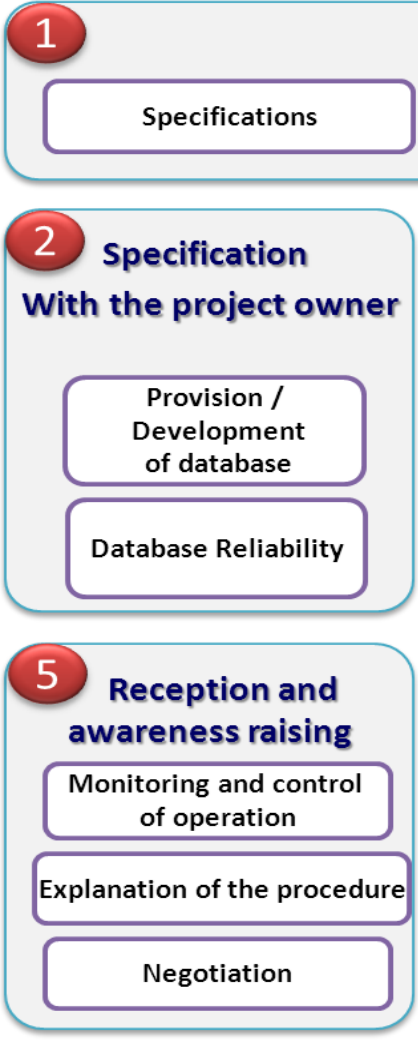

\section{Requirements Management}

Call for proposal
Contract

\section{(3) Validation of} beneficiary lists

Eligibility management

Capacity Management

\section{6}

Validation of files

Managing Approvals

Demolition management

\section{Management of communication}

Elaboration of the
Communication message Convocation management

Managing Approvals By the authorities

Management of the distribution of convocations

Claims management

7 Management of allocations

Management of payments

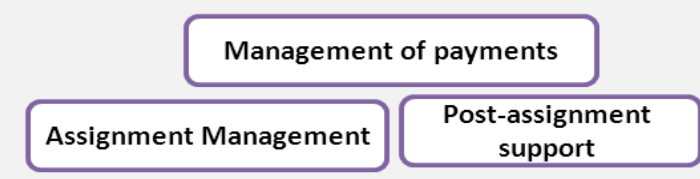

Evaluation \& Closing

Fig. 2 Business process mapping of social mediation

\begin{tabular}{|c|c|c|c|c|}
\hline \multirow{2}{*}{ Tasks } & \multicolumn{4}{|c|}{ RACI } \\
\hline & Responsible & Approver & Consulted & Informed \\
\hline $\begin{array}{l}\text { Drawing up the census list: Information on the } \\
\text { shelter forms }\end{array}$ & Mediator & Local commission & Agent of authority & \\
\hline Checking the census list & Mediator & Local commission & Agent of authority & \\
\hline Identification List of beneficiaries & Local commission & & & \\
\hline $\begin{array}{l}\text { Elaboration of information message for eligible } \\
\text { shacks }\end{array}$ & Mediator & & & Local commission \\
\hline Scheduling Convocations & Mediator & $\begin{array}{l}\text { Local commission } \\
\text { Caïd }\end{array}$ & & \\
\hline $\begin{array}{l}\text { Distribution of convocations by lot of } 50 \\
\text { convocation }\end{array}$ & Mediator & & & \\
\hline $\begin{array}{l}\text { Awareness and explanation of the procedure for } \\
\text { setting up the file }\end{array}$ & $\begin{array}{l}\text { Mediator } \\
\text { Caïd }\end{array}$ & & & \\
\hline $\begin{array}{l}\text { Validation of the file and assignment per } \\
\text { household }\end{array}$ & Local commission & & Mediator & \\
\hline visit of the shack before demolition & Mediator & & & \\
\hline Demolition of shack & Beneficiary & Mediator & & Local commission \\
\hline Preparation of the demolition certificate & Caïd & & & \\
\hline Payment order elaboration & Beneficiary & $\begin{array}{l}\text { Local } \\
\text { Commission }\end{array}$ & & \\
\hline Assignment & Local commission & & & \\
\hline
\end{tabular}

Table 1: RACI Matrix 


\section{Process Sheet of Requirement Management process:} The flowing figure presents a sample of process details developed for the requirement management process. The main characteristics are (Title, description, actors, inputs, business rules, outputs and support tools and means)

\begin{tabular}{|l|l|}
\hline Process title & Requirement Management \\
\hline Actors & Project owner, Mediator \\
\hline Description & $\begin{array}{l}\text { The objective of this process is to } \\
\text { define the project requirements for } \\
\text { the mediator who will assist the } \\
\text { project owner for the rehabilitation of } \\
\text { slums }\end{array}$ \\
\hline Inputs & $\begin{array}{l}\text { Strategic orientations in the field of } \\
\text { housing and urban policy }\end{array}$ \\
\hline Business rules & Not Applicable \\
\hline Outputs & Request for proposal \\
\hline $\begin{array}{l}\text { Means and tools of } \\
\text { support }\end{array}$ & $\begin{array}{l}\text { Stakeholder's needs clearly defined. } \\
\text { A validated specification }\end{array}$ \\
\hline
\end{tabular}

\section{Integrated methodology of social mediation project management}

This methodological framework, inspired by the Project Management Body of Knowledge (PMBOK) [9], provides support for project managers and project team members. The methodology establishes best practices in project management, as recognized by the Project Management Institute (PMI). This framework is intended primarily as a tool for identifying and structuring a project.

The project management process presented in this framework is based on a typical project life cycle, which is divided into four generic phases: initiating and scoping with contractors, planning, execution and closure.

Although the processes of the four phases are illustrated in a linear and sequential manner, it is important to understand that the project management process and its phases are characterized by their highly iterative nature. The steps and phases of the project management framework are briefly described below.

\section{Preliminary phase:}

This is the preliminary phase of social mediation; it deals with the management of the request of proposal and the contractual management with the operator of the mediation.

\section{Initiating phase:}

This phase aims to identify more precisely the main parameters of the project, such as the project's purpose, objectives, scope, project environment, stakeholders, risks and preliminary estimates.

\section{Planning phase:}

The main purpose of the Planning phase is to develop the Project Plan that will be used to achieve the objectives of the project. This plan specifies what, who, when and how much the project can be realized.

\section{Executing phase:}

The Execution phase put into practice the Project Plan. It involves carrying out the activities defined in the Project Plan to meet project requirements. It also involves coordinating resources, supervising and managing the project and managing requests for change.

\section{Closing phase:}

The purpose of the Closing phase is to present a retrospective of the project activities, to identify lessons learned and to close and archive the documentation used to manage the project.

The overall diagram (Fig. 3) is presented below:

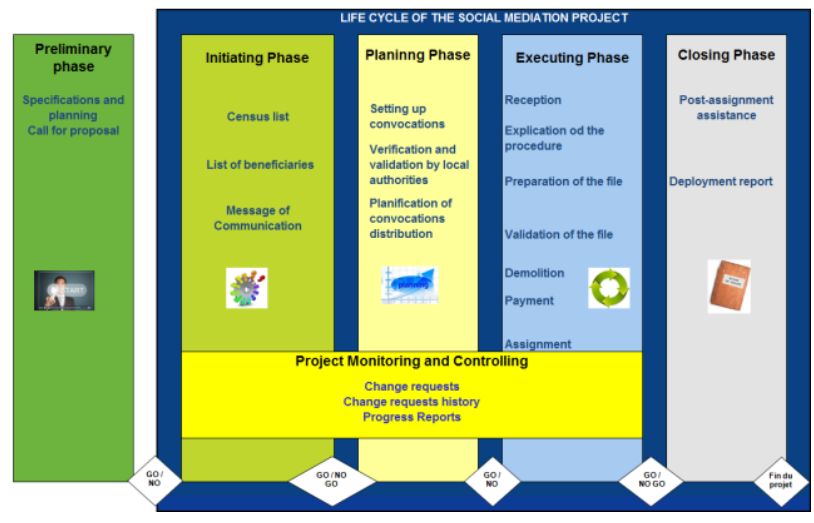

Fig. 3 Integrated methodology of social mediation project management

\section{Conclusions}

An important conclusion of this paper is that social mediation business can be managed through a centricapproach that gives more guidelines and practices to structure this field. The proposed framework is composed mainly of the following elements:

- General mapping of macro processes,

- Processes sheets (Processes details)

- The distribution of processes over the different project phases.

The findings will provide, for both researchers and practitioners, a practical approach to support organizations in attempt to improve their way to manage social mediation projects. 


\section{References}

[1] Chang, J. F. (2016). Business process management systems: strategy and implementation. CRC Press.

[2] Brandenburg, H., \& Wojtyna, J. P. (2006). L'approche processus, mode d'emploi. Editions Eyrolles.

[3] Blokdijk, G. (2008). The Service Level Agreement SLA Guide-SLA book, Templates for Service Level Management and Service Level Agreement Forms. Fast and Easy Way to Write your SLA. Lulu. com.

[4] Smith, M. L., Erwin, J., \& Diaferio, S. (2005). Role \& responsibility charting (RACI). In Project Management Forum (PMForum) (p. 5).

[5] Rdiouat, Y., Nakabi, N., Kahtani, K., \& Semma, A. (2012). Towards a new approach of continuous process improvement based on CMMI and PMBOK. International Journal of Computer Science Issues(IJCSI).

[6] Saglio-Yatzimirsky, M. C. (2013). Dharavi: from mega-slum to urban paradigm. Routledge.

[7] Govinda, R. (2015). Marie-Caroline Saglio-Yatzimirsky, Dharavi, From Mega-Slum to Urban Paradigm.

[8] Dupont, V., Saglio-Yatzimirsky, M. C., \& Fernandes, L. L. (2013). Public Policies and the "Treatment" of Slums. Megacity Slums: Social Exclusion, Space and Urban Policies in Brazil and India, 1, 165.

[9] Rose, K. H. (2013). A Guide to the Project Management Body of Knowledge (PMBOK® Guide) —Fifth Edition. Project Management Journal, 44(3), e1-e1. 